\title{
METODE PENDIDIKAN DALAM AL-QUR'AN \\ (KAJIAN TAFSIR TEMATIK)
}

Oleh Ahmad Syaifulloh

Dosen STAI Khozinatul Ulum Blora

Email :al_magfiroh@yahoo.co.id

\begin{abstract}
As a component of science, the method can deliver an educational process can achieve their education goal quickly and precisely. This will happen when the methods of education and teaching which is in line with the substance and purpose. Therefore an educator must master many learning methods, so that he can choose the method that is appropriate to the circumstances. In the world of Islamic education, learning and educational goals let in accordance with the Koran and the Hadith as the source of the basic teachings of Islam. In the two sources of the law there had to be a strong foundation on educational methods, as has been done by the Prophet Muhammad in preaching and educating Muslims. Through the study of thematic interpretation (Tafsir thematic), this study aims to uncover methods of education contained in the Koran, as well as explore the hadiths relevant to such methods. The results of this study indicate that there are several methods of education in the Quran include: storytelling (Hud : 120), and answer method (Al-Baqarah : 189), the method of wisdom, advice, discussion (An- Nahl : 125), and the method of demonstration (al-Kahf : 77).
\end{abstract}

Keywords: Methods, Education, Tafsir thematic. thematic interpretation.

\begin{abstract}
Abstak
Sebagai komponen ilmu, metode dapat mengantar suatu proses pendidikan dapat mencapai tujuan pendidikanya dengan cepat dan tepat. Hal ini akan terjadi bila mana metode pendidikan dan pengajaran ini sejalan dengan substansi dan tujuan. Maka dari itu seorang pendidik harus menguasai banyak metode pembelajaran, sehingga ia dapat memilih metode yang tepat sesuai dengan situasi dan kondisi. Dalam dunia pendidikan Islam, proses dan tujuan pendidikan hendaklah sesuai dengan al-Quran dan Hadits sebagai sumber pokok ajaran Islam. Dalam ke dua sumber hukum tersebut pastilah terdapat landasan yang kuat tentang metode pendidikan, sebagaimana yang telah dilaksanakan oleh Nabi Muhammad dalam berdakwah dan mendidik umat Islam. Melaui kajian tafsir tematik, penelitian ini bertujuan untuk mengungkap metode pendidikan yang terdapat dalam al-Quran, serta menggali hadits-hadits yang relevan dengan metode tersebut. Hasilnya menunjukkan bahwa terdapat beberapa metode pendidikan dalam al-Quran di antaranya : metode bercerita (QS. Huud ayat 120), metode tanya jawab (QS. al-Baqarah ayat 189), metode hikmah, nasehat, diskusi (QS. an-Nahl ayat 125), dan metode demonstrasi (QS. al-Kahfi ayat 77).
\end{abstract}

Kata Kunci : Metode, Pendidikan, Tafsir tematik. 


\section{Ahmad Syaifulloh}

\section{A. PENDAHULUAN}

Pendidikan Islam di sekolah formal hingga saat ini masih belum menunjukkan kinerja yang lebih baik dibandingkan dengan pendidikan lainnya di Indonesia. Lembaga-lembaga pendidikan Islam di Indonesia yang bermutu dan kompetitif baik ditingkat dasar maupun tinggi masih dapat dihitung dengan jari. Masih banyak aspek yang harus dibenahi dalam sistem pendidikan Islam, di antaranya yaitu persoalan profesionalisme tenaga pendidik yang masih jauh dari harapan, dan metode pembelajaran yang monoton, masih bersifat konservatif, kurang kreatif, dan masih mementingkan kemajuan dibidang kognitif saja.

Begitu juga dalam pelaksanaan pembelajaran saat ini, khusunya dalam pendidikan agama Islam, masih didominasi oleh pendekatan yang berpusat pada guru (teacher-centered approach). Sedangkan pendekatan yang berpusat pada siswa (student-centered approach) masih merupakan teori dan konsep yang belum terintregasi secara menyeluruh dalam rencana dan pelaksanaan pembelajaran.

Hal utama yang dapat dilakukan oleh guru untuk mengatasi problematika di atas adalah bagaimana meningkatkan pemahaman peserta didik tentang mata pelajaran agama Islam dan meningkatkan motivasi mereka, sehingga terbentuklah sebuah kesadaran dalam diri mereka bahwa apa yang telah mereka pelajari harus diamalakan dalam kehidupan sehari-hari. Oleh karena itu, disamping memiliki sumber daya yang memadai, seorang guru harus lebih kreatif untuk mengembangankan metode pendidikan yang lebih variatif dan juga memperhatikan 


\section{Metode Pendidikan Dalam Al-Qur'an}

(Kajian Tafsir Tematik)

pendekatan pembelajaran yang terpusat pada peserta didik (student centered approach).

Sebagai komponen ilmu, metode dapat mengantar suatu proses pendidikan dapat mencapai tujuan pendidikanya dengan cepat dan tepat. Hal ini akan terjadi bila mana metode pendidikan dan pengajaran ini sejalan dengan substansi dan tujuan. Di samping itu, metode juga harus sesuai dengan situasi dan kondisi yang ada. Maka dari itu seorang pendidik harus menguasai banyak metode pembelajaran, sehingga ia dapat memilih metode yang tepat sesuai dengan situasi dan kondisi. ${ }^{1}$

Dalam dunia pendidikan Islam, proses dan tujuan pendidikan hendaklah sesuai dengan al-Quran dan Hadits sebagai sumber pokok ajaran Islam. Dalam ke dua sumber hukum tersebut pastilah terdapat landasan yang kuat tentang metode pendidikan, sebagaimana yang telah dilaksanakan oleh NabiMuhammad kepada kaum muslimin pada waktu tersebut, dan agar dalam proses pendidikan dapat mencontoh kesuksesan Nabi Muhammad dalam berdakwah, mendidik, dan mengajar para sahabat beliau itu. Maka dari itu, melaui kajian tafsir tematik, penelitian ini bertujuan untuk mengungkap metode pendidikan yang terdapat dalam al-Quran, serta menggali hadits-hadits yang relevan dengan metode tersebut.

\section{B. TEKS AYAT}

1. Surat Huud ayat 120

\footnotetext{
${ }^{1}$ Zakiah Darajat, Metodik Khusus Pengajaran Agama Islam, (Jakarta: Direktorat Jendral Pembinaan Kelembagaan Agama Islam, 1985), hlm. 2.
} 
Ahmad Syaifulloh

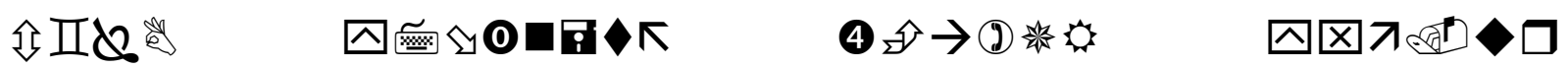
$\rightarrow$ O Q

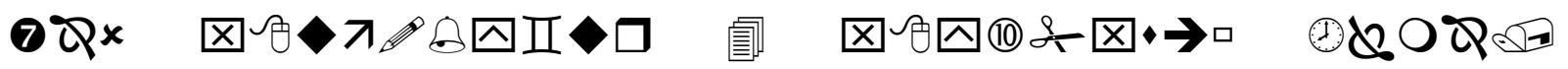

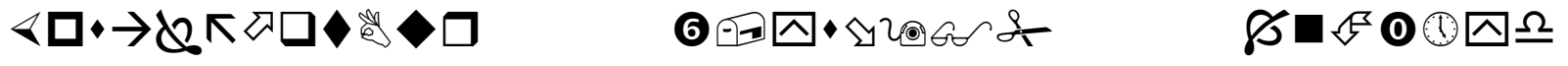

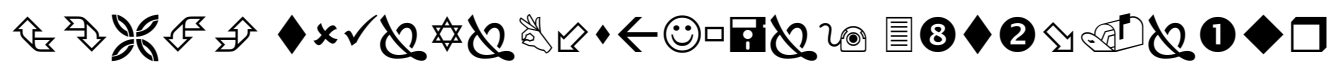
2. Surat al-Baqarah ayat 189

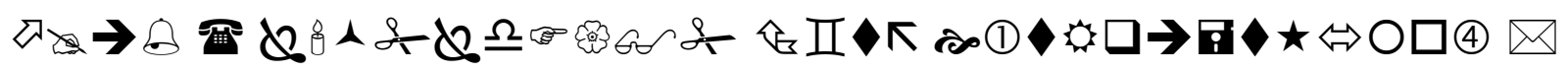

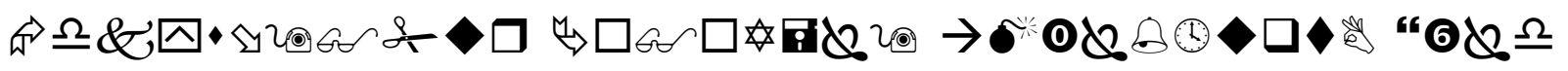

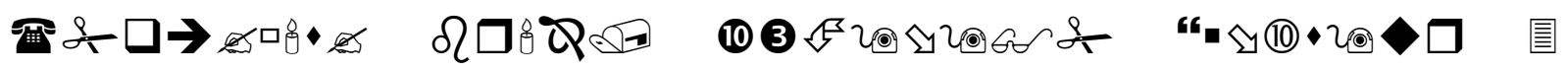

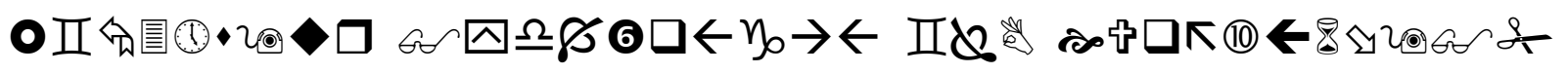

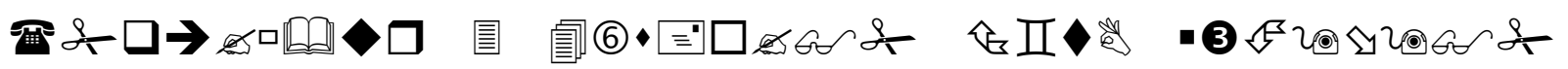
亩 G

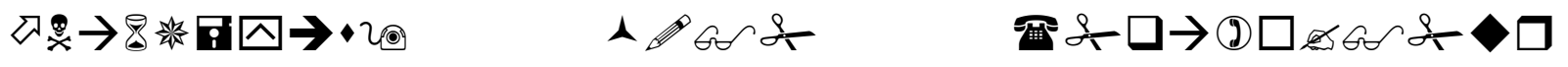
估

3. Surat an-Nahl ayat 125

囚

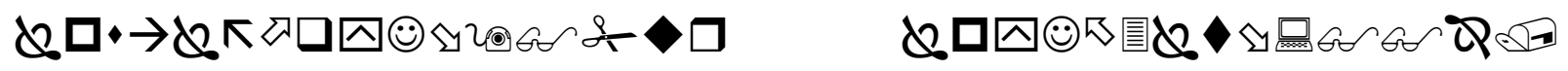

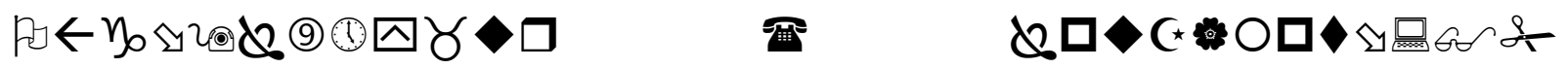

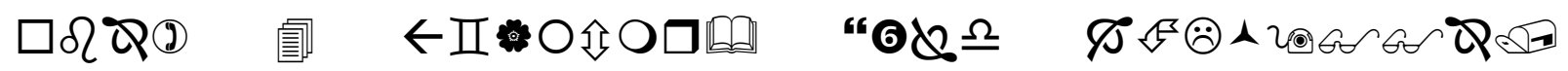

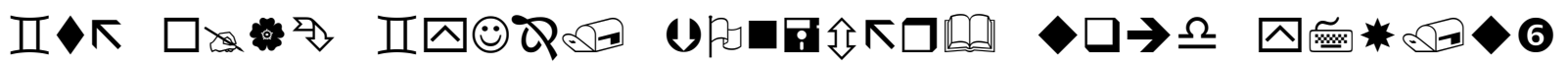




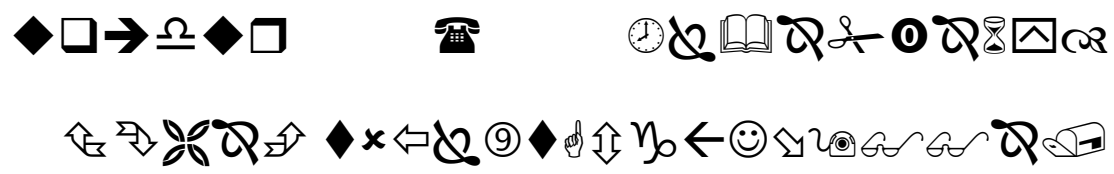

4. Surat al-Kahfi ayat 77

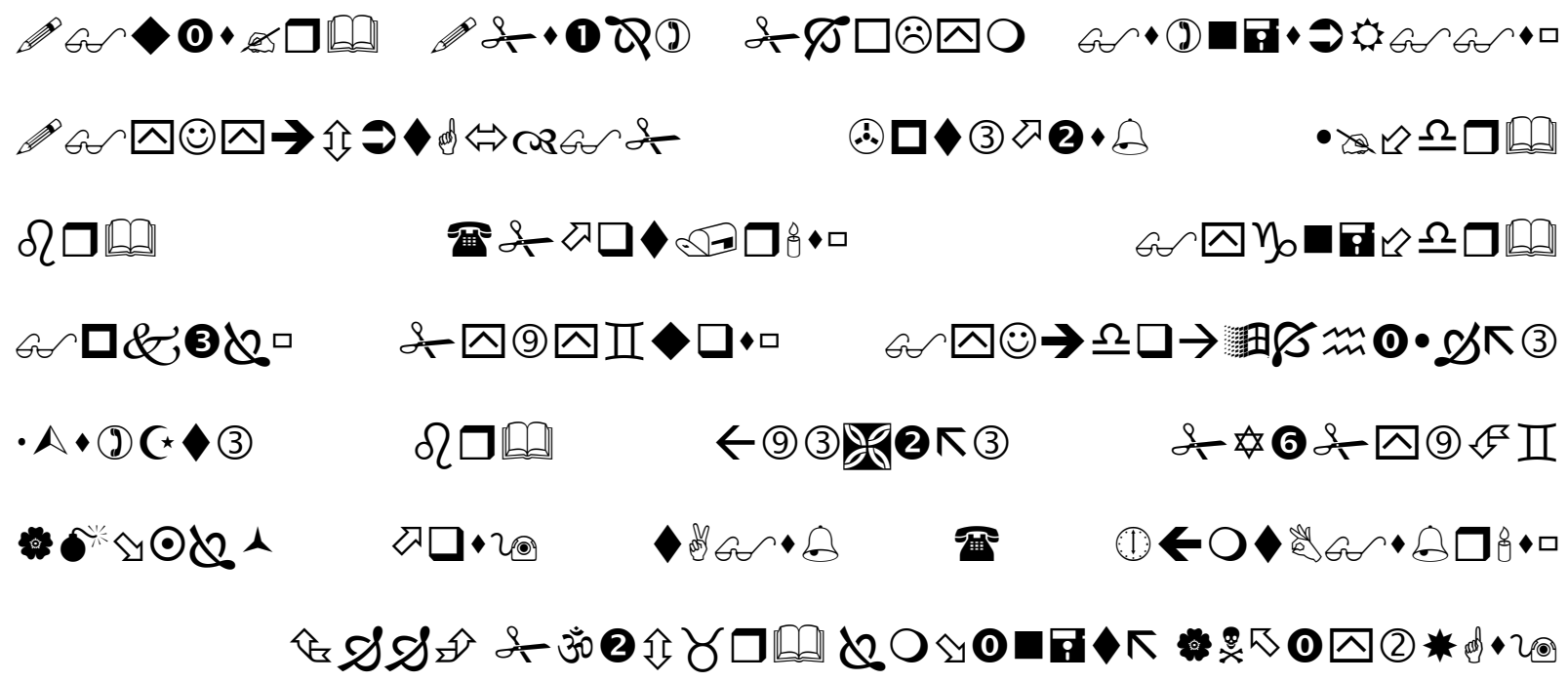

\section{TERJEMAH}

1. Surat Huud ayat 120

120. Dan semua kisah dari rasul-rasul kami ceritakan kepadamu, ialah kisah-kisah yang dengannya kami teguhkan hatimu; dan dalam surat Ini Telah datang kepadamu kebenaran serta pengajaran dan peringatan bagi orang-orang yang beriman.

2. Surat al-Baqarah ayat 189

189. Mereka bertanya kepadamu tentang bulan sabit. Katakanlah: "Bulan sabit itu adalah tanda-tanda waktu bagi manusia dan (bagi ibadat) haji; dan bukanlah kebajikan memasuki rumah-rumah dari belakangnya, akan tetapi kebajikan itu ialah kebajikan orang yang bertakwa. dan masuklah ke rumah-rumah itu dari pintu-pintunya; dan bertakwalah kepada Allah agar kamu beruntung.

3. Surat an-Nahl ayat 125 


\section{Ahmad Syaifulloh}

125. Serulah (manusia) kepada jalan Tuhan-mu dengan hikmah dan pelajaran yang baik dan bantahlah mereka dengan cara yang baik. Sesungguhnya Tuhanmu dialah yang lebih mengetahui tentang siapa yang tersesat dari jalan-Nya dan dialah yang lebih mengetahui orang-orang yang mendapat petunjuk.

\section{Surat al-Kahfi ayat 77}

77. Maka keduanya berjalan; hingga tatkala keduanya sampai kepada penduduk suatu negeri, mereka minta dijamu kepada penduduk negeri itu, tetapi penduduk negeri itu tidak mau menjamu mereka, Kemudian keduanya mendapatkan dalam negeri itu dinding rumah yang hampir roboh, Maka Khidhr menegakkan dinding itu. Musa berkata: "Jikalau kamu mau, niscaya kamu mengambil upah untuk itu".

\section{PENAFSIRAN}

Perkataan "metode" berasal dari bahasa Yunani, yaitu "methodos". Kata ini terdiri dari dua suku kata, yaitu"metha" yang berarti melalui atau melewati dan "hodos" yang berarti jalan atau cara. Maka metode memiliki arti suatu jalan yang dilalui untuk mencapai tujuan. Dalam bahasa Inggris dikenal dengan term method dan way yang diterjemahkan sebagai cara. Sedangkan dalam bahasa Arab kata metode diungkapkan dalam berbagai kat seperti kata al-thoriqoh, al-manhaj, dan alwashilah. Al-thariqoh berarti jalan, al-manhaj berarti system, dan al-washilah berarti mediator atau perantara. Sedangkan secara terminology metode adalah suatu jalan yang ditempuh seseorang supaya sampai pada tujuan tertentu baik dalam lingkungan ataupun dalam perniagaan maupun dalam kaitan ilmu pengetahuan dan lainya. ${ }^{2}$ Ada pula yang mendefinisikan bahwa metode adalah suatu cara kerja yang sistematis seperti cara kerja ilmu pengetahuan. ${ }^{3}$

\footnotetext{
${ }^{2}$ Ismail SM, Strategi Agama Islam Berbasis PAIKEM, (Semarang: Rasail Media Group, 2008), hlm. 7

${ }^{3}$ Zakiah Darajat, Metodik Khusus ..., hlm. 1
} 
Sedangkan pendidikan atau pembelajaran itu dalam arti luas adalah suatu proses untuk mengembangkan semua aspek kepribadian manusia, yang mencakup pengetahuanya, nilai dan sikapnya serta ketrampilanya. Semua itu bertujuan untuk mencapai kepribadian individu yang lebih baik. ${ }^{4}$

Jadi, berdasarkan masing-masing pengertian dari metode dan pembelajaran tersebut di atas, maka dapat disimpulkan bahwa pengertian metode pembelajaran adalah suatu cara kerja yang sistematis untuk mengembangkan semua aspek kepribadian manusia yang mencakup pengetahuanya, nilai serta sikapnya, dan ketrampilanya yang bertujuan untuk mencapai kepribadian individu yang lebih baik.

Ayat-ayat di atas mengandung tema metode pembelajaran. Ayat pertama menjelaskan tentang metode bercerita. Ayat kedua menjelaskan tentang metode tanya jawab. Ayat ketiga menjelaskan tentang metode hikmah, mauidhoh hasanah (ceramah), dan mujadalah (diskusi). Ayat keempat menjelaskan tentang metode demonstrasi (praktik).

\section{Metode Bercerita}

Metode bercerita terdapat dalam QS. Huud ayat 120.Ayat ini menerangkan bahwa Allah swt. telah menceritakan kisah Rasul-rasul terdahulu bersama umatnya, seperti peristiwa perbantahan dan permusuhan di antara mereka, diselamatkannya umat yang beriman dan diazabnya kaum yang tidak beriman, keluhan para Nabi karena kaumnya mendustakan dan menyakitinya dan sebagainya, semuanya itu berguna untuk meneguhkan hati Rasulullah saw., laksana gunung yang tak

4 Ahmad Munib, dkk, Pengantar Ilmu Pendidikan, (Semarang UPK MKK Unnes. 2004), hlm. 28. 


\section{Ahmad Syaifulloh}

tergoyahkan oleh apa pun untuk mengemban tugas kerasulan dan menyiarkan dakwahnya karena telah mencontoh kepada Rasul-rasul sebelumnya yang telah mendapat tantangan hebat sekali dari kaumnya. Selain dari itu, kisah-kisah tersebut juga menanamkan kebenaran yang mantap, keyakinan yang mendalam tentang apa yang diserukan para Rasul, seperti akidah bahwa Allah swt. adalah Esa, bertobat dan beribadah kepada-Nya dengan ikhlas, meninggalkan kejahatan baik yang nyata maupun yang tidak nyata. Kesemuanya itu merupakan pengajaran dan peringatan yang bermanfaat bagi orang-orang yang percaya bahwa umat terdahulu itu ditimpakan azab kepadanya adalah karena mereka telah berbuat aniaya dan kerusakan di muka bumi.

Ibnu Katsir mengenai ayat ini menjelaskan bahwa segala cerita yang diceritakan oleh Allah kepada Nabi Muhammad saw, seperti cerita para Rasul yang terdahulu beserta umat mereka, bagaimana peristiwa perdebatan dan permusuhan, ketabahan para Nabi menahan pendustaan dan penderitaan, bagaimana Allah menolong orang-orang mukmin sebagai tentara allah dan menghinakan orang-orang kafir sebagai musuh-Nya, semua itu untuk memantapkan hati Nabi Muhammad saw, supaya mereka para Rasul terdahulu menjadi tauladan bagi Nabi Muhammad saw. ${ }^{5}$

Imam at-Thabari juga memberI penjelasan tentang ayat ini bahwa Allah swt berfirman : segala yang Kami ceritakan kepada kamu (Muhammad) tentang cerita para Rasul (orang-orang sebelum kamu), yaitu cerita yang dapat memantapkan hati

\footnotetext{
${ }^{5}$ Ismail bin Umar bin Katsir ad-Dimisqi, Tafsir al-Quran al-Adzim, (al-Maktabah ats-Tsamilah, 1999), juz. 4, hlm. 363.
} 
kamu, maka janganlah susah dengan kedustaan kaummu, dan menolak apa yang telah kamu sampaikan kepada mereka, dan janganlah berkecil hati sehingga kamu meninggalkan sebagian yang telah Kami turunkan kepadamu, sekiranya mereka berkata : tidakkah diturunkan kepadanya rahasia langit atau malaikat datang bersamanya? ketika kamu telah mengetahui apa yang telah dihadapi oleh para Rasul sebelum kamu dan umat mereka. ${ }^{6}$

Begitu juga Imam Fahruddin Muhammad bin Umar ar-Razi menjelaskan bahwa sesungguhnya Allah swt. dalam menceritakan kisah-kisah dalam surat ini terdapat dua faedah : pertama, memantapkan hati nabi Muhammad untuk menyampaikan risalah kenabian, sabar dan menahan hal-hal yang menyakitkan, demikian itu karena manusia ketika mendapat cobaan, kemudian mengetahui bahwa dia mempunyai teman senasib, maka beban penderitaannya yang dirasakan oleh hatinya akan menjadi ringan. Maka ketika Rasul saw mendengar cerita tersebut dan mengetahui keadaan para Nabi terdahulu, maka mudah bagi Rasul saw untuk menahan penderitaan dari kaumnya dan dapat mengatasinya dengan kesabaran. Kedua, dalam surat tersebut telah datang kepada Rasul saw yaitu suatu kebenaran, mauidzoh dan peringatan bagi orang-orang mukmin. ${ }^{7}$

Dari hal tersebut kita dapat mengetahui bahwa dalam menyampaikan pendidikan dapat melalui metode cerita, guru dapat menceritakan hal-hal pada masa lampau atau sejarah yang berkaitan dengan pelajaran dan tema yang sedang

\footnotetext{
${ }^{6}$ Abu Ja'far Muhammad bin Jarir bin Yazid bin Katsir al-Qurtuby, Jami' al-Bayan fi Ta'wil al-Quran, (al-Maktabah atsTsamilah, 2000), juz. 15, hlm. 539.

${ }^{7}$ Muhammad bin Umar ar-Razi, Mafatibul Ghoib, (al-Maktabah ats-Tsamilah), juz. 18, hlm. 63.
} 


\section{Ahmad Syaifulloh}

diajarkannya, karena cerita itu akan mudah diterima oleh murid dan akan membekas pada hati mereka, kemudian akan mudah untuk memahami pelajaran, mengambil isi pesan yang terdapat dalam cerita tersebut dan dapat dijadikan contoh tauladan, serta menjadi motivasi bagi mereka. Seperti halnya Allah swt menceritakan kisah-kisah para Nabi terdahulu kepada Rasul saw, sehingga beliau bisa mendapatkan pelajaran, mengambil contoh dan mendapatkan inspirasi dari kisah tersebut, sehingga dengan bertambahnya pengetahuan maka dengan mudah Rasul saw dapat mengatasi cobaan-cobaan dari kaumnya dengan kesabaran dan bijaksana.

Mengapa Allah swt dalam ayat ini menyebutkan kisah yang dapat memantapkan hati, karena pengetahuan ilahiyah tidak terlepas dari sesuatu yang menerima dan hal yang harus diterima. Hal yang menerima tersebut yaitu hati, dan hati yang tidak siap untuk menerima pengetahuan ilahiyah tersebut maka tidak akan menghasilkan manfaat dengan mendengarkan cerita tersebut. Dan hal yang harus diterima terebut yaitu apa yang terdapat dalam surat ini telah mencakup kebenaran, nasehat, dan peringatan, yaitu tiga hal yang menjadikan kemulyaan dan keagungan.

Berdasarkan hal tersebut, maka dalam menyampaikan pendidikan melalui metode cerita ini, hendaknya memilih cerita yang pas dengan tema, dan mudah dipaham oleh siswa, serta cerita yang bersisi kebenaran, nasehat, dan peringatan, sehingga melalui cerita tersebut siswa lebih mudah menangkap isi pesan atau inti dalam cerita tersebut. 


\section{Metode Pendidikan Dalam Al-Qur'an \\ (Kajian Tafsir Tematik)}

Begitu juga terdapat hadits Nabi yang senada dengan metode cerita tersebut, seperti hadits Abu Hurairah ra :

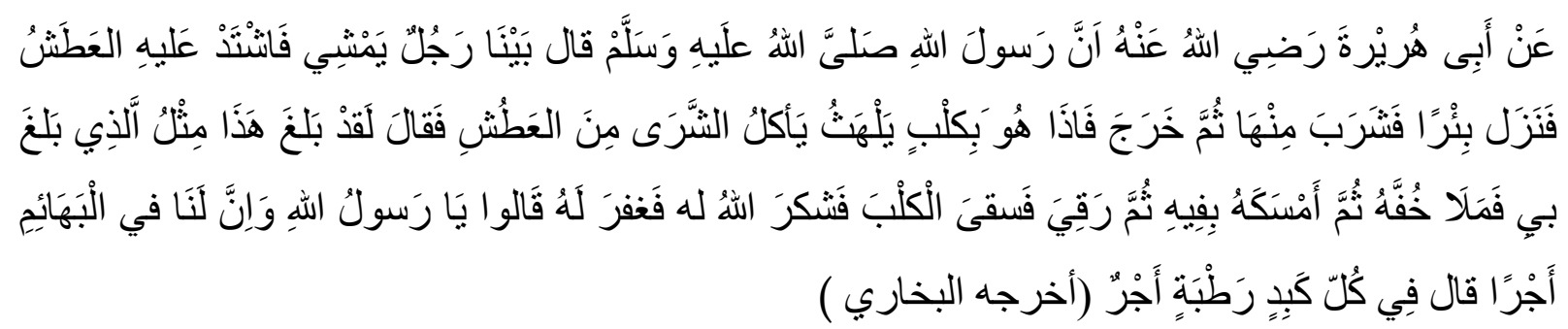

Artinya: "Dari Abu Hurairah ra, sesungguhnya rasulullah SAW bersabda: Ketika seorang laki-laki sedang berjalan-jalan tiba-tiba ia merasa sangat haus sekali kemudian ia menemukan sumur lalu ia masuk kedalamnya dan minum, kemudian ia keluar (dari sumur). Tiba-tiba datang seekor anjing menjulur-julurkan lidahnya ia menjilati tanah karena sangat haus, lelaki itu berkata: anjing itu sangat haus sebagaimana aku, kemudian masuk ke sumur lagi dan ia penuhi sepatunya (dengan air), kemudian ia sambil menggigit sepatunya dan ia beri minum anjing itu kemudian Allah bersyukur kepadanya dan mengampuninya, sahabat bertanya, wahai Rasulullah: adakah kita mendapat pahala karena kita menolong hewan? Nabi SAW menjawab: disetiap yang mempunyai limpa hidup ada pahalanya. (HR. Bukhori).

Dalam hadits tersebut Nabi Muhammad menceritakan tentang seseorang yang memberi minum anjing yang sangat kehausan, kemudian dia mendapatkan pujian dari Allah dan dihapus dosa-dosanya. Meskipun dalam kebaikan ini memberi minum hewan yang dianggap haram dan najis dalam Islam yaitu anjing, tetapi karena manusia diajarkan untuk memiliki rasa kasih sayang terhadap semua mahluk Allah, maka hal itu menjadi anjuran apalagi terhadap hewan bahkan manusia yang sedang membutuhkan pertolongan. Menurut Badru ad-Din al-'Aini al-Hanafi pada dasarnya hadits tersebut didasarkan untuk memperlihatkan rasa kasih saying terhadap makhluk Allah. ${ }^{8}$

\footnotetext{
${ }^{8}$ Badru ad-Din al-'Aini al-Hanafi, 'Umdatu al-Qori Sarh Shohih al-Bukhari, (al-Maktabah ats-Tsamilah), juz. 19, hlm. 46.
} 


\section{Ahmad Syaifulloh}

Hadits di atas mengandung pesan umum bahwa pendidikan dengan metode cerita dapat menumbuhkan kesan yang mendalam pada peserta didik, sehingga dapat memotivasi mereka untuk berbuat yang baik dan menjauhi hal yang buruk, hal itu dikarenakan cerita memang banyak disukai dan merupakan yang baik untuk menanamkan norma-norma yang terimpan dalam cerita tersebut. Bahkan kaedah ini merupakan metode yang menarik yang dilakukan Rasulullah. Para sahabat pun mudah untuk memahaminya dan memberikan repon yang positif. Hal ini menunjukkan sejak dulu metode cerita memang cocok untuk dikembangkan dalam pendidikan dan pengajaran.

Allah SWT berfirman dalam surat Yusuf: 111

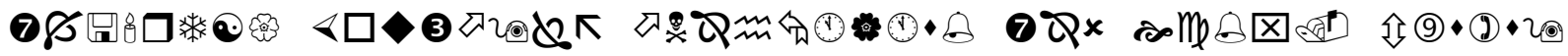

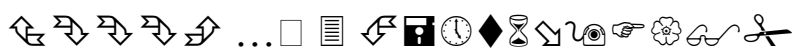

Artinya: "Sesungguhnya pada kisah-kisah mereka itu terdapat pengajaran bagi orangorang yang mempunyai akal."

Jadi, berdasarkan penjelasan di atas, kita dapat memahami bahwa dalam kedua sumber Islam yaitu al-Quran dan Hadits terdapat dalil yang senada dengan metode bercerita dalam pendidikan. Sudah tentu metode ini perlu pengembangan yang lebih menarik dan tepat sasaran, sehingga melalui metode ini dapat mencapai hasil yang diinginkan.

\section{Metode tanya jawab}

Metode tanya jawab terdapat pada QS. al-Baqarah ayat 189. Pada ayat tersebut terdapat tiga keterangan, yaitu tentang pertanyaan sahabat tentang hilal beserta 
jawabannya, keterangan tentang memasuki rumah melalui pintunya, dan perintah bertakwa kepada Allah. Mengenai masalah yang pertama dijelaskan pada kalimat pertama dalam ayat ini, yaitu يسئلونك عن الأهلة yang artinya mereka bertanya tentang bulan sabit. Dari hal ini kita mengetahui terjadi tanya jawab antara sahabat dengan Nabi Muhammad saw. Mengenai sebab turunya ayat ini Muhamad al-Alusy Abu Fadl menerangkan dalam kitabnya bahwa Ibnu Asakir menceritakan dengan sanad dhoif bahwa Mu'ad bin Jabbal dan Tsa'labah bin Ghanam bertanya kepada Rasul : Ya Rasulallah Bagaimana keadaan hilal yang nampak dan muncul kecil seperti benang, kemudian bertambah besar, rata dan bulat, kemudian terus menerus berkurang dan mengecil sehingga kembali seperti semula, bulan itu tidak menetapi pada bentuk yang tetap (satu bentuk)? Kemudian turunlah ayat tersebut. ${ }^{9}$

Mengenai maksud munculnya pertanyaan tersebut dan jawaban yang telah diberikan oleh Allah kepada Nabi Muhammad tentang hal tersebut, Imam Fahruddin ar-Razi menulis dalam tafsirnya bahwa firman Allah يسئلونك عن الأهلة tidak menjelaskan sesungguhnya mengapa mereka bertanya, tetapi jawannya itu seperti menunjukkan pada maksud pertanyaan, karena firman Allah قُلْ هِىَ مَوَاقِيتُ للِنَّاس وَالْحَجِ menunjukkan bahwa pertanyaan mereka bermaksud pada tujuan faedah dan hikmah tentang perubahan keadaan hilal yang mengecil dan membesar, kemudian al-Quran dan hadits selaras dalam perihal pertanyaan tersebut."10

\footnotetext{
${ }_{9}^{9}$ Muhamad al-Alusy Abu Fadl, Rubul Ma'ani, (al-Maktabah ats-Tsamilah, tt), juz. 2, hlm. 71.

${ }^{10}$ Muhammad bin Umar ar-Razi, Mafatibul Ghoib, juz. 5, hlm. 103.
} 


\section{Ahmad Syaifulloh}

Sedangkan tentang hal yang kedua, yaitu tentang perintah memasuki rumah lewat pintu disebutkan

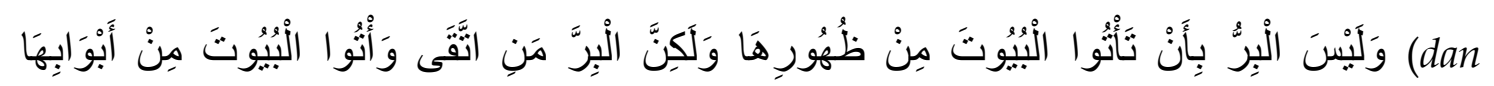
bukanlah kebajikan memasuki rumah-rumah dari belakangnya, akan tetapi kebajikan itu ialah kebajikan orang yang bertakwa. dan masuklah ke rumah-rumah itu dari pintu-pintunya).

Mengenai asal mula diturunkannya ayat ini karena pada zaman jahiliyah orang-orang yang ihram memasuki rumah mereka melalui atap dan membuat tangga, kemudian hal ini ditanyakan pula oleh sahabat sehingga turunlah ayat ini. Seperti keterangan Imam Thabary dengan mengungkapkan sebuah hadits:

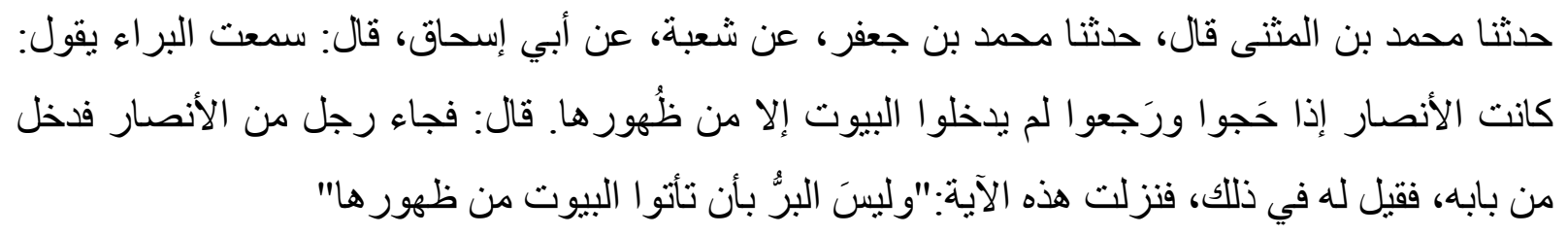

“Telah menceritakan kepadaku Muhammad bin Mutsanna, dia berkata telah bercerita kepadaku Muhammad bin Ja'far dari Syu'bah, dari Abi Ishaq, dia berkata : aku mendengar alBara' berkata : orang-orang Anshar ketika berhajji dan ketika pulang mereka tidak masuk rumah kecuali melalui atas rumah (atap). Dia berkata : kemudia ada seorang laki-aki dari kaum anshar masuk melalui pintu rumahnya. Kemudia hal ini ditanyakan kepada rasullullah, kemudian turunlah :"وليسَ البرٌّ بأن تأتوا البيوت من ظهور ها"

Sebenarnya dalam al-Quran terdapat sebelas ayat yang menggunakan kata يَسْئَلْونَلَكَ عَنِ (mereka bertanya tentang), yaitu : surat al-Baarah ayat :186, 189, 217, 219, 280, 222 , surat al-A'raf ayat 187 , surat an-Naazi' aat ayat 42 , surat al-Kahfi ayat 83 , surat al-Isra' ayat 85, dan surat Thaha ayat 105.

Dari keterangan tersebut jika dihubungkan dengan metode pendidikan, maka ayat tersebut menjelaskan tentang metode Tanya jawab, sebagaimana para sahabat

${ }^{11}$ Abu Ja'far at-Thabary, Jami' al-Bayan..., juz. 3, hlm. 556. 


\section{Metode Pendidikan Dalam Al-Qur'an \\ (Kajian Tafsir Tematik)}

bertanya keada Rasulullah, sehingga mereka mendapatkan penjelasan sesuai dengan maksud pertanyaan mereka dan sesuai dengan keadaan mereka.

Tentang metode tersebut juga senada dengan sebuah hadits Nabi Muhammad saw yang diriwayatkan oleh Imam Muslim :

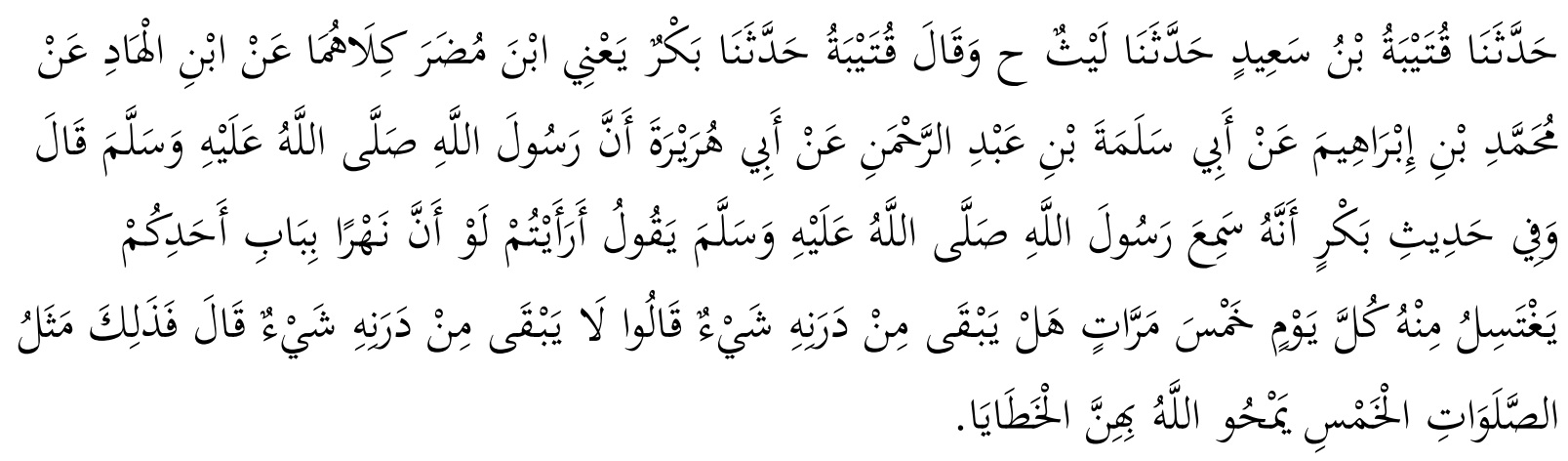

Artinya: "Hadis Qutaibah ibn Sa'id, hadis Lâis kata Qutaibah hadis Bakr yaitu ibn Mudhar dari ibn Hâd dari Muhammad ibn Ibrahim dari Abi Salmah ibn Abdurrahmân dari Abu Hurairah r.a. Rasulullah saw. bersabda; Bagaimana pendapat kalian seandainya ada sungai di depan pintu salah seorang di antara kalian. Ia mandi di sana lima kali sehari. Bagaimana pendapat kalian? Apakah masih akan tersisa kotorannya? Mereka menjawab, tidak akan tersisa kotorannya sedikitpun. Beliau bersabda; Begitulah perumpamaan salat lima waktu, dengannya Allah menghapus dosa-dosa". (Muslim, I: 462-463)

Hadis di atas tergolong syarîf marfu' dengan kualitas perawi yang sebagian tergolong şiqah dan şiqah şubut, sedangkan Abu Hurairah adalah sahabat Rasulullah saw. Selain itu juga terdapat hadits :

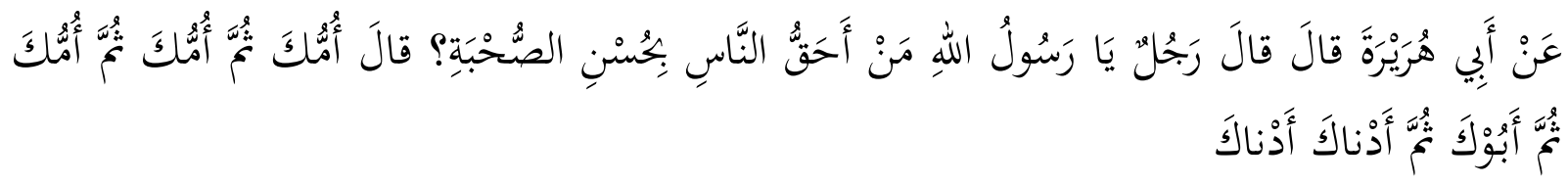

Artinya: "dari Abu Hurairah ra, Ia berkata seseorang laki-laki datang pada Rasulullah $S A W$, kemudian ia bertanya, wahai Rasulullah siapa orang yang paling berhak aku hormati? Beliau menjawab: Ibumu, ia berkata, kemudian siapa? Beliau menjawab: Ibumu, ia berkata, kemudian siapa? Beliau menjawab: kemudian bapakmu, kemudian saudara terdekatmu." (HR. Bukhari :5626) 


\section{Ahmad Syaifulloh}

Hadits di atas menerangkan tentang seorang sahabat bertanya kepada rasulullah tentang masalah sillaturahim dan adab. Kata "rajul" dalam hadits tersebut yang dimaksud adalah mu'awiyah bin Khayidah. ${ }^{12}$

Dari keterangan tersebut baik dari al-Quran maupun dari kedua hadits di atas, dapat diketahui bahwa Nabi Muhammad saw juga menggunakan metode Tanya jawab dalam memperikan pengetahuan kepada para sahabat dan hasilnya jga para sahabat mampu untuk memahami dari keterangan yang diberikan oleh Nabi. Metode bertanya ini untuk mengajak si pendengar agar fokus dengan pembahasan. Metode tanya jawab, apakah pembicaraan antara dua orang atau lebih, dalam pembicaraan tersebut mempunyai tujuan dan topik tertentu. Metode dialog berusaha menghubungkan pemikiran seseorang dengan orang lain, serta mempunyai manfaat bagi pelaku dan pendengarnya.

Metode tanya jawab juga disebut dengan metode dialog, tentang dialog dapat dilakukan oleh seseorang dengan orang lain, baik mendengar langsung atau melalui bacaan. Pembaca dialog akan mendapat keuntungan berdasarkan karakteristik dialog, yaitu topik dialog disajikan dengan pola dinamis sehingga materi tidak membosankan, pembaca tertuntun untuk mengikuti dialog hingga selesai. Melalui dialog, perasaan dan emosi akan terbangkitkan, topik pembicaraan disajikan bersifat realistik dan manusiawi. Dalam Alquran banyak memberi informasi tentang dialog, di antara bentuk-bentuk dialog tersebut adalah dialog khitâbi, ta'abbudi, deskritif,

\footnotetext{
12 Badru ad-Din al-'Aini al-Hanafi, 'Umdatu al-Qori ..., juz. 32, hlm. 138.
} 
naratif, argumentatif serta dialog nabawiyah. Metode tanya jawab, sering dilakukan oleh Rasul saw. dalam mendidik akhlak para sahabat. Dialog akan memberi kesempatan kepada peserta didik untuk bertanya tentang sesuatu yang tidak mereka pahami. Pada dasarnya metode tanya jawab adalah tindak lanjut dari penyajian ceramah yang disampaikan pendidik. Dalam hal penggunaan metode ini, Rasulullah saw. menanyakan kepada para sahabat tentang penguasaan terhadap suatu masalah atau beliau ingin memberikan pengertian dengan menyampaikan pertanyaan dahulu untuk memfokuskan para sahabat dan menarik perhatian mereka, sehingga muncul rasa ingin tahu mereka terhadap informasi yang akan disampaikan oleh beliau.

Metode tanya jawab merupakan metode yang memungkinkan adanya komunikasi langsung yang bersifat Two wag traffic sebab pada saat yang sama terjadi dialog antara guru dan siswa, sehingga komunikasi ini terlihat adanya hubungan timbal balik antara guru dan siswa. Adapun metode ini bertujuan untuk mengetahui sampai sejauh mana materi pelajaran yang telah dikuasai oleh siswa, untuk merangsang siswa berfikir dan memberi kesempatan pada siswa untuk mengajukan masalah yang belum paham. ${ }^{13}$

Dengan demikian metode tanya jawab memang dapat menjadi sebuah metode yang menarik dalam pembelajaran, karena peserta didik akan menjadi aktiv dengan memberikan pertanyaan atau memberikan jawaban tentang apa yang mereka ketahui. Sehingga pengetahuan yang mereka dapat lebih bisa tertanam dalam pikiran

${ }^{13}$ Nana Sudjana, Dasar-Dasar Proses Belajar Mengajar, (Bandung: Sinar Baru Algesindo, 1995), hlm. 78. 


\section{Ahmad Syaifulloh}

mereka dan mereka akan terbiasa dalam menjawab soal-soal ketika dilaksanakan ujian. Tentunya metode ini dapat dikembangkan sesuai dengan kondisi peserta didik masing-masing.

\section{Metode Hikmah}

Metode Hikmah terdapat dalam QS. an-Nahl ayat 125. Surat an-Nahl termasuk golongan surat Makiyah dan terdiri dari 128 ayat. Di dalam surat ini terdapat firman Allah swt yang menerangkan tentang lebah, yaitu ayat ke-68 yang artinya : "Dia Tuhanmu yang telah mewahyukan kepada lebah." Sebab itulah surat ini dinamakan dengan surat an-Nahl yang berarti lebah.

Bila kita cermati ternyata lebah adalah hewan yang unik, yaitu hewan yang bisa membangun rumahnya dengan segi enam dan tiap sudutnya saling berhubungan dengan yang lain. hal ini dapat dihubungkan dengan system dan metode pendidikan, dengan filsafah lebah ini sitem pendidikan hendaknya memiliki suatu system yang kuat dengan membangun jaringan-jaringan yang terhubung kesegala komponen pendidikan sehingga mudah terjalin komunikasi dan kerjasama dalam menciptakan pendidikan yang baik. Networking tersebut dapat mencakup peserta didik sebagai obyek pendidikan, guru sebagai subyek pendidikan, penyelenggara pendidikan baik itu Kepala sekolah beserta staf-stafnya, komite sekolah, dan dinas-dinas yang terkait, sealin itu juga mencakup orang tua/wali peserta didik yang peran cukup penting dalam mengawasi anak ketika berada di luar lingkungan sekolah. Jika komponen pendidikan tersebut terhubung dengan baik dan 
kuat serta dapat memainkan perannya masing-masing ,maka akan terjadi kerjasama yang kuat dan tak terpisahkan, sehingga akan menghasilkan pendidikan yang diharapkan.

Tentang ayat ini al-Maraghi menerangkan bahwa : Hai Rasul, serulah orangorang yang kau diutus kepada mereka dengan cara menyeru mereka kepada syari'at yang telah digariskan Allah bagi makhluk-Nya melalui wahyu yang diberikan kepadaMu, dan memberi mereka pelajaran dan peringatan yang diletakkan di dalam kitab-Nya sebagai hujah atas mereka, serta selalu diingatkan kepada mereka, seperti diulang-ulang dalam surat ini. Dan bantahlah mereka dengan bantahan yang lebih baik daripada bantahan lainnya seperti memberi maaf kepada mereka jika mereka mengotori kehormatanmu serta bersikaplah lemah lembut terhadap mereka dengan menyampaikan kata-kata yang baik. ${ }^{14}$

Begitu juga dalam Tafsir Munir disebutkan bahwa : Ajaklah kepada jalan Tuhanmu wahai Muhammad (kepada agama Allah) dengan Hikmah dengan ucapan kebijaksanaan. Ini adalah merupakan dalil yang bersih yang benar dari penyerupaanpenyerupaan yang keliru. Adapun yang disebut dengan nasehat yang baik adalah nasehat-nasehat dan pelajaran-pelajaran yang bermanfaat dan perkataan yang bercahaya. ${ }^{15}$

Ibnu Katsir tentang ayat ini juga menerangkan bahwa Allah SWT berfirman, memerintahkan Rasul-Nya Muhammad saw untuk menyeru makhluk ke jalan Allah

\footnotetext{
14 Al-Maraghy, Tafsir Al-Maraghy. Terj. Hery Noer Ali, dkk., (Semarang : Toha Putra, 1974) hlm. 161-162

15 Wahbah Al-Zuhaeli, Tafsir Munir, (Damasqus : Darul Fikri, 1991) hlm. 267
} 


\section{Ahmad Syaifulloh}

dengan cara hikmah (perkataan yang tegas dan benar). Ibnu Jarir berkata, “dan demikianlah apa yang diturunkan Allah kepada Muhammad dari kitab, sunnah dan pelajaran yang baik, yaitu tentang sesuatu yang di dalamnya terdapat larangan dan ketetapan bagi manusia. Mengingatkan mereka dengan itu semua (al-Kitab, sunnah dan mauizhoh) agar mereka takut akan siksa Allah SWT.16

Disebutkan pula dalam Tafsir HAMKA keterangan tentang ayat ini, yaitu : Serulah kepada jalan Tuhanmu dengan kebijaksanaan dan pendidikan yang baik, dan. bantahlah mereka dengan. cara yang lebih baik." (pangkal ayat 125). Ayat ini mengandung ajaran .kepada Rasul s.a.w. tentang cara melancarkan dakwah, atau seruan terhadap manusia agar mereka berjalan di atas jalan Allah. Pertama, Kata "Hikmah" itu kadang-kadang diartikan orang dengan Filsafat. Padahal dia adalah inti yang lebih halusdari filsafat. Filsafat hanya dapat dipahamkan oleh orang-orang yang telah terlatih fikirannya dan tinggi pendapat logikanya. Tetapi Hikmat dapat menarik orang yang belum maju kecerdasannya dan tidak dapat dibantah oleh orang yang lebih pintar. Kebijaksanaan itu bukan saja dengan ucapan mulut, melainkan termasuk juga dengan tindakan dan sikap hidup, kadang-kadang lebih berhikmat "diam" daripada "berkata". Kedua ialah Al-Mau'izhatul Hasanah, yang diartikan pendidikan yang baik, atau pesan-pesan yang baik, yang disampaikan sebagai nasehat. Ketiga ialah "Jadilhum billati hiya ahsan", bantahlah mereka dengan cara yang lebih baik. Kalau telah terpaksa timbul perbantahan atau pertukaran pikiran, yang di

\footnotetext{
16 Ibnu Katsir, Tafsir Ibnu Katsir, (Beyrut : Daarul Fikri, 1980) hlm.592
} 
zaman kita ini disebut polemik, ayat ini menyuruh agar dalam hal yang demikian, kalau sudah tidak dapat dielakan lagi pilihlah jalan yang sebaik-baiknya. Diantaranya ialah memperbedakan pokok soal yang tengah dibicarakan dengan perasaan benci atau sayang kepada pribadi orang yang tengah diajak berbantah. ${ }^{17}$

Dari penjelasan tersebut bila dihubungkan dengan metode pendidikan, maka dapat diketahui dalam surat an-Nahl ayat 125 terdapat tiga bentuk metode pendidikan, yang pertama yaitu metode hikmah.Hal ini diketahui dari kata

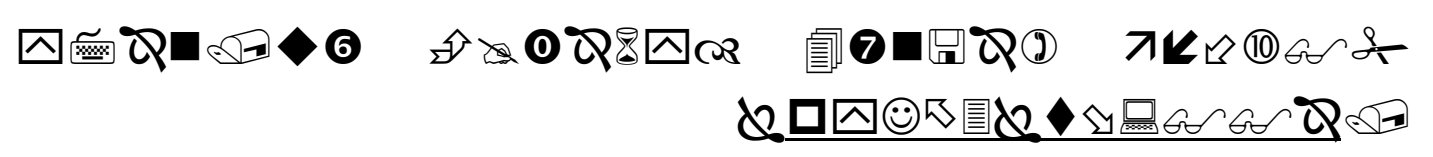

Kata Al-hikmah sendiri mempunyai arti ilmu, keadilan, falsafah, kebijaksanaan, dan uraian yang benar. ${ }^{18}$ Jadi kalimat tersebut di atas dapat diartikan sebagai mengajak kepada jalan Allah dengan cara ilmu, keadilan, falsafah, kebijaksanaan, dan uraian yang benar. Dalam konteks pendidikan dengan metode hikmah ini hendaknya selalu mempertimbangkan berbagai faktor dalam proses belajar mengajar, baik faktor subjek, obyek, sarana, media dan lingkungan pengajaran, sehingga semua factor tersebut dapat disikapi dengan kearifan dan kebijaksanaan untuk mencapai pendidikan yang baik, menyenangkan dan tepat sasaran.

Tentang kalimat ini Imam al-Qurtubi menjelaskan bahwa Allah swt memerintahkan kepada Nabi Muhammad untuk mengajak kepada agama Allah dan syariat-Nya dengan cara yang halus dan lemah lembut tidak dengan keras dan

\footnotetext{
${ }^{17}$ Hamka. Tafsir Al-Azhar. (Jakarta : Pustaka Panjimas,1992) hlm. 321-322
}

${ }^{18}$ Husen Al-Habsy, Kamus Arab Lengkap, ( Bangil : YAPPI, 1989), hlm. 64 


\section{Ahmad Syaifulloh}

bermusuhan, begitu juga hendaknya kaum muslimin dalam berdakwah juga menggunakan cara ini pula samapi hari qiyamat. ${ }^{19}$ Jadi menurut Imam al-Qurtubi kata Hikmah dalam ayat tersebut diartikan dengan lemah lembut atau dengan istilah lain disebut dengan qaulan layyinan. Hal ini senada dengan firman Allah : "Maka berbicaralah kamu berdua kepadanya dengan kata-kata yang lemah lembut, mudah-mudahan ia ingat atau takut".

Menurut Quraish Shihab, kata hikmah antara lain berarti yang paling utama dari segala sesuatu, baik pengetahuan maupun perbuatan. Dia adalah pengetahuan atau tindakan yang bebas dari kesalahan dan atau kekeliruan. Hikmah juga diartikan sebagai sesuatu yang bila digunakan/diperhatikan akan mendatangkan kemaslahatan dan kemudahan yang besar atau lebih besar, serta menghalangi terjadinya mudharat atau kesulitan yang besar atau lebih besar. ${ }^{20}$

Thahir Ibnu 'Asyur, menyatakan bahwa hikmah adalah nama himpunan segala ucapan atau pengetahuan yang mengarah kepada perbaikan keadaan dan kepercayaan manusia secara seimbang. Lebih lanjut beliau menjelaskan pendapat arRaghib al-Ashfahani yang menyatakan sacara singkat bahwa hikmah adalah sesuatu yang mengena kebenaran berdasarkan ilmu dan akal. Dengan demikian, menurut Thabathaba'i, hikmah adalah argumen yang menghasilkan kebenaran yang tidak diragukan, tidak mengandung kelemahan tidak juga kekaburan. Dalam hal ini, Quraish Shihab juga mengutip pendapat al-Biqa'i yang menggarisbawahi bahwa, al-

${ }^{19}$ Imam Al-Qurtubi, Al-Jami'ul Abkam Al-Qur'an, ( Bairut-Libanon : Darulkutub al-ilmiyah, 1413 H/1993 M), hlm. 131.

${ }^{20}$ M. Quraish Shihab, Tafsir Al-Mishbah, volume 6, (cet. II; Jakarta: Lentera Hati, 2009), h. 775. 


\section{Metode Pendidikan Dalam Al-Qur'an}

(Kajian Tafsir Tematik)

hakim yakni yang memiliki hikmah, harus yakin sepenuhnya tentang pengetahuan dan tindakan yang diambilnya, sehingga dia tampil dengan penuh percaya diri, tidak berbicara dengan ragu, atau kira-kira tidak pula melakukan sesuatu dengan cobacoba. ${ }^{21}$

Sedangkan An-Naisaburi menjelaskan bahwa yang dimaksud Al-hikmah adalah tanda atau metode yang mengandung argumentasi yang kuat (Qoth'i) sehingga bermanfaat bagi keyakinan.22 Melaui metode hikmah ini dakwah dan pendidikan harus menggunakan kearifan dalam bertuturkata atau berkomunikasi sehingga kata-kata tersebut memiliki tendensi yang kuat dan jelas, sehingga bermanfaat bagi peserta didik untuk memahami materi pelajaran dan mendpatkan kebenaran. Tentunya diperlukan interaksi yang kondusif antara guru dan peserta didik agar kegiatan belajar mengajar dapat berjalan dengan baik.

Hal tersebut senada dengan sebuah hadits Nabi Muhammad saw yang diriwayatkan oleh Imam Muslim :

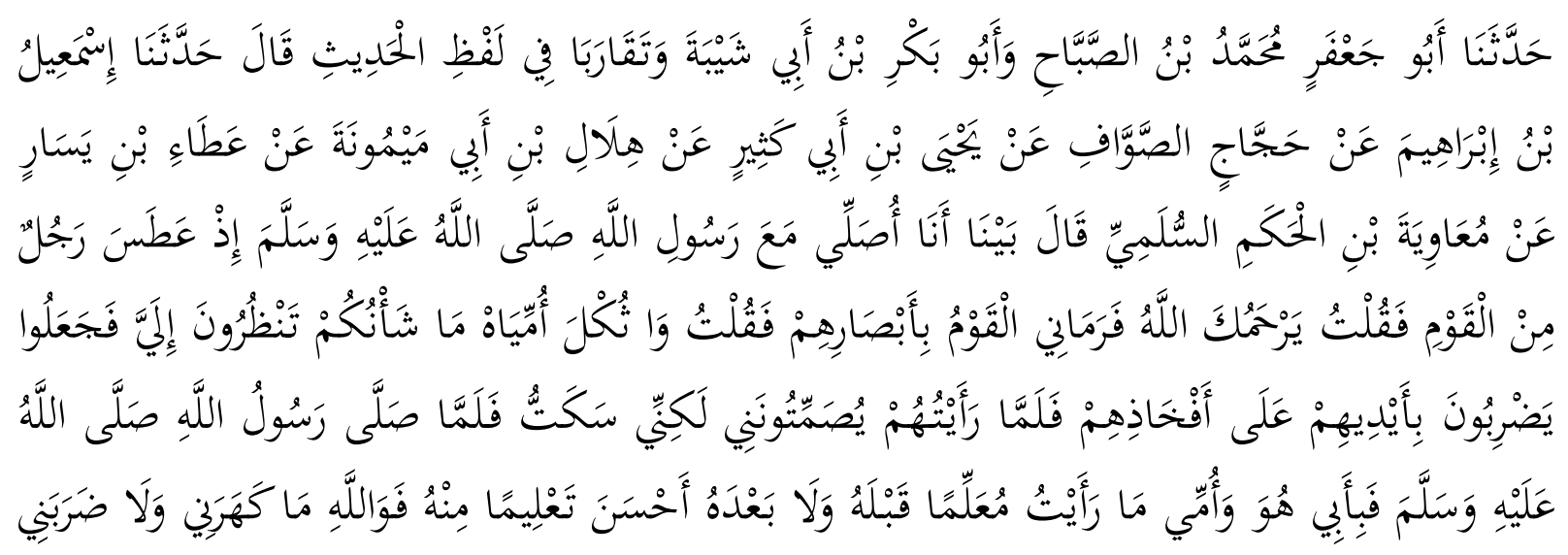

21 Ibid.

22 An-Naisaburi, Tafsir Ghoroibil Qur'an wa roghoibil Furqon, ( Bairut-Libanon : Darul kutubul Ilmiuah, 1996), hlm. 316 


\section{Ahmad Syaifulloh}

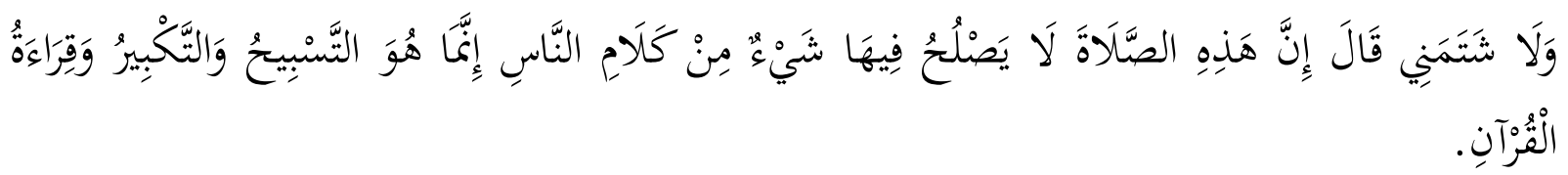

Artinya: "Hadis dari Abu Ja'far Muhammad ibn Shabah dan Abu Bakr ibn Abi Syaibah, hadis Ismail ibn Ibrahim dari Hajjâj as-Shawwâf dari Yahya ibn Abi Kaşir dari Hilâl ibn Abi Maimũnah dari 'Atha' ibn Yasâr dari Mu'awiyah ibn Hakam as-Silmiy, Katanya: Ketika saya salat bersama Rasulullah saw., seorang dari jama'ah bersin maka aku katakan yarhamukallâh. Orang-orang mencela saya dengan pandangan mereka, saya berkata: Celaka, kenapa kalian memandangiku? Mereka memukul paha dengan tangan mereka, ketika saya memandang mereka, mereka menyuruh saya diam dan saya diam. Setelah Rasul saw. selesai salat (aku bersumpah) demi Ayah dan Ibuku (sebagai tebusannya), saya tidak pernah melihat guru sebelumnya dan sesudahnya yang lebih baik pengajarannya daripada beliau. Demi Allah beliau tidak membentak, memukul dan mencela saya. Rasulullah saw. (hanya) bersabda: Sesungguhnya salat ini tidak boleh di dalamnya sesuatu dari pembicaraan manusia. Ia hanya tasbîh, takbîr dan membaca Alquran." (Muslim, t.t, I: 381).

Dalam hadits tersebut dapat diketahui bahwa Rasulullah saw memberikan pengetahuan dan pengajaran melalui perkataan yang lembut tetapi juga tegas. Sehingga para sahabat yang menerimanya tidak merasa terpojokkan atau merasa tersinggung, tetapi mereka merasa lega dan dapat menerima apa yang disampaikan oleh Rasulullah saw tersebut. Di samping itu Rasulullah juga mimiliki sifat bijaksana sehingga dalam masalah tersebut beliau menghadapinya dengan kearifan melalui hikmah yaitu perkataan yang lembut dan tegas serta sesuai dengan kondisi para shahabat tersebut.

Jadi yang dimaksud dengan metode hikmah dalam pendidikan yaitu penyampaian dengan kearifan dan kebijaksanaan melalui kata-kata lemah lembut tetapi juga tegas dengan mengunakan alasan-dalil dan argumentasi yang kuat serta menggunakan uraian yang benar sehingga dengan proses ini para peserta didik memiliki keyakinan dan kemantapan dalam menerima materi pelajaran untuk 
sebagai bekal dan pedoman untuk memperoleh ilmu yang lebih luas lagi dan dapat mengembangkan apa yang telah dipahaminya sesuai dengan kemajuan dan tuntutan zaman.

\section{Metode Mauidzah hasanah (ceramah)}

Metode ini terdapat dalam QS. Nahl ayat 125, hal ini diketahui dari kata

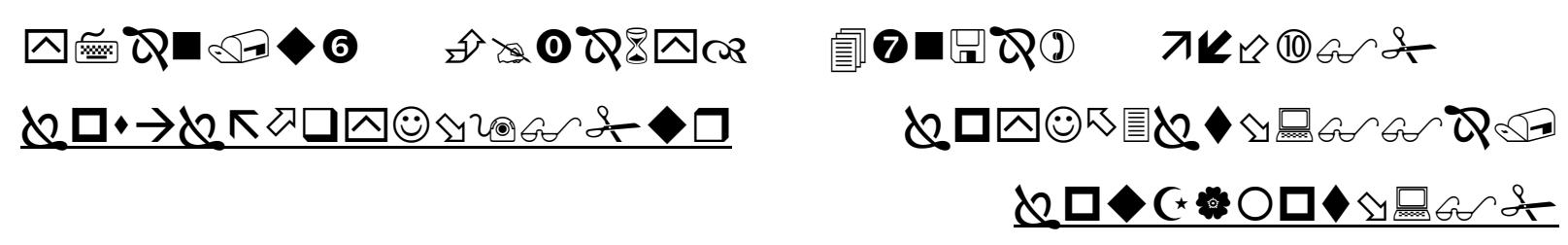

Kata Maudzah hasanah (الموعظة الحسنة) dapat diartikan dengan nasehat, wejangan, pengajaran, pendidikan yang baik. Para mufasir berbeda-beda dalam menjelaskan kata mauidzah hasanah tersebut. Al-Imam Jalaludin Asy-Syuyuti mengartikan kata "Al-Mauidzah" itu dengan kalimat مواعظه أو القول الرقيق artinya perkataan yang lembut. ${ }^{23}$ Ibnu Katsir menafsiri Al-mauidzah al-hasanah sebagai pemberian peringatan kepada manusia, mencegah dan menjauhi larangan sehingga dengan proses ini mereka akan mengingat kepada Allah. ${ }^{24}$ At-Thobari mengartikan mauidzah hasanah dengan "Al-ibr al-jamilah" yaitu perumpamaan yang indah bersal dari kitab Allah sebagai hujjah, argumentasi dalam proses penyampaian. ${ }^{25}$

Metode mauidzah hasanah ini dalam konteks pendidikan dapat diartikan dengan pembelajaran dengan nasehat atau wejangan dalam kebaikan yang

\footnotetext{
${ }^{3}$ Al-Imamul Jalalain, Tafsir Al-Quranul Adzim, ( Indonesia, Maktabah Dar ihya al-kutub al-arabiyah, tt), hlm. 104.

${ }^{24}$ Ibnu Katsir, Tafsir Ibnu Katstir ( CD. Holly Qur,an ).

25 Ja'far Muhmaad ibn Jarir Ath-Thobarii, Tafsir Ath-Thobari ; Jami'ul BAyan Ta'wilul Qur'an, ( Bairut-Libanon : Darul kutubul Ilmiuah, 1996), hlm. 663.
} 


\section{Ahmad Syaifulloh}

disampaikan melalui perkataan lembut diikuti dengan perilaku hasanah. Melalui metode ini dalam kegiatan belajar mengajar guru dapat membimbing dan mengarahkan peserta didik ke arah yang benar dengan menanamkan norma-norma yang berlaku, sehingga peserta didik memiliki pengetahuan untuk membedakan hal yang haq dan batil serta mampu mengaplikasikannya dalam kehidupan sehari-hari.

Pendidika tidak hanya menanamkan pengetahuan saja tetapi hendaknya diiringi dengan akhlak yang baik sehingga moral peserta didik dapat tertata dengan baik seiring dengan ilmu yang mereka peroleh dari proses pembelajaran. Begitu pula seorang guru juga hendaknya memiliki akhlak yang baik pula dan mampu memberikan nasehat atau wejangan yang cocok sesuai dengan keaaan peserta didik. Sehingga tercapailah tujuan pendidikan yang diinginkan, yaitu pendidikan yang mewujudkan manusia yang memiliki kemampuan ilmu yang memadai serta diiringi etika atau akhlak al-karimah.

Dengan melalui prinsip mauidzoh hasanah dapat memberikan pendidikan yang menyentuh, meresap dalam kalbu. Ada banyak pertimbangan (multi approach) agar penyampaian materi bisa diterima oleh peserta didik diantaranya : a).Pendekatan Relegius, yang menekankan bahwa manusia adalah makhluk relegius dengan bakat-bakat keagamaan. Metode pendidikan Islam harus merujuk pada sumber ajaran Islam yaitu Al-Qur'an dan Al-Hadits, b). Dasar Biologis, pertumbuhan jasmani memegang peranan yang sangat penting dalam proses pendidikan, c).Dasar Psikologis, metode pendidikan Islam bisa effektif dan efesien bila didasarkan pada 


\section{Metode Pendidikan Dalam Al-Qur'an (Kajian Tafsir Tematik)}

perkembangan psikis meliputi motivasi, emosi, minat, sikap, keinginan, kesediaan, bakat-bakat dan kecakapan akal intelektual, d). Dasar Sosiologis, pendekatan social interaksi antar siswa, guru dengan siswa sehingga memberikan dampak positif bagi keduanya. ${ }^{26}$

Terdapat sebuah hadits riayat Umar bin Abi Salamah yang sesuai dengan metode mauidzah hasanah ini, yaitu :

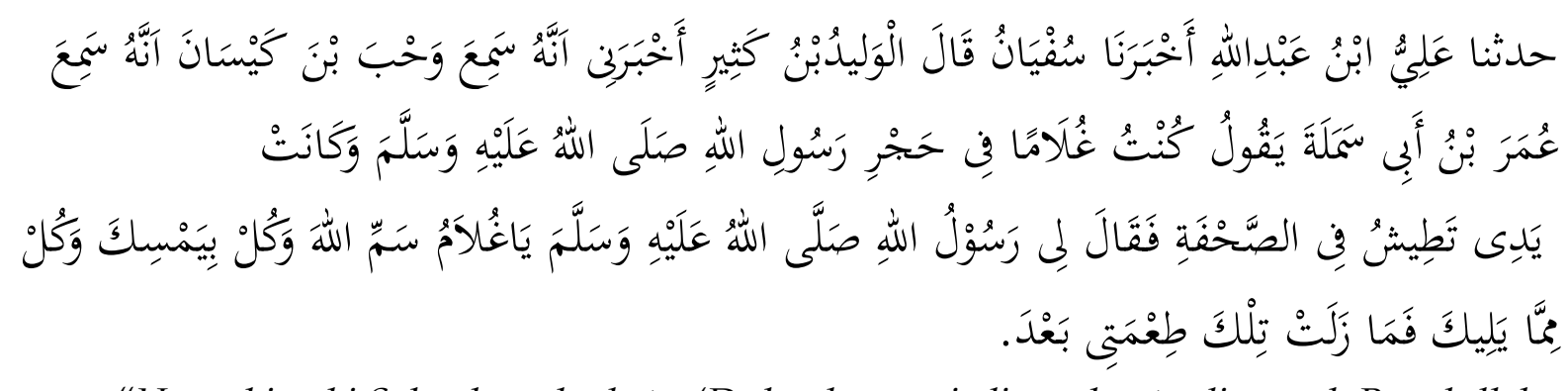

“Umar bin abi Salmah r.a berkata, 'Dulu aku menjadi pembantu di rumah Rasulullah saw. Ketika makan, biasanya aku mengulurkan tangan ke berbagai penjuru. Melihat itu beliau berkata, 'Hai ghulam, bacalah basmallah, makanlah dengan tangan kananmu, dan makanlah a pa yang ada di dekatmu"

Juga terdapat sebuah hadits riayat Imam Bukhari yang sesuai dengan metode ini, yaitu :

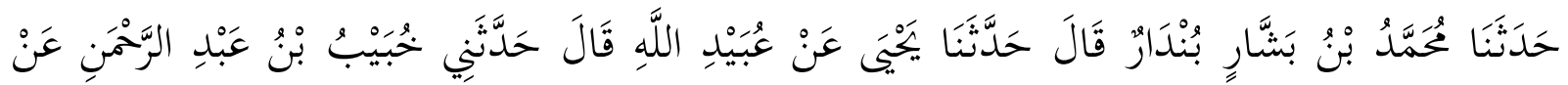

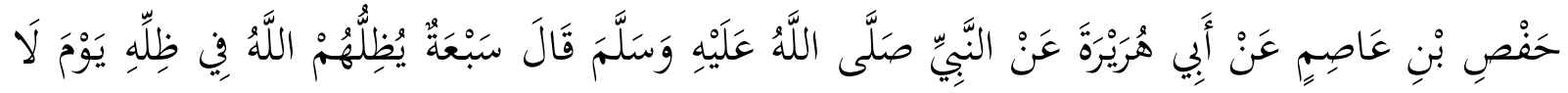

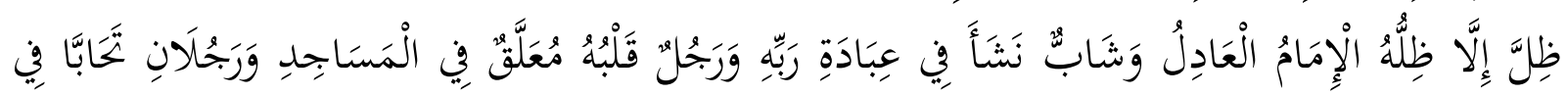

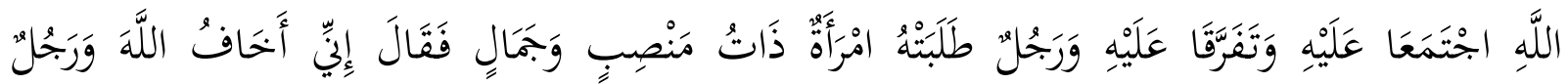

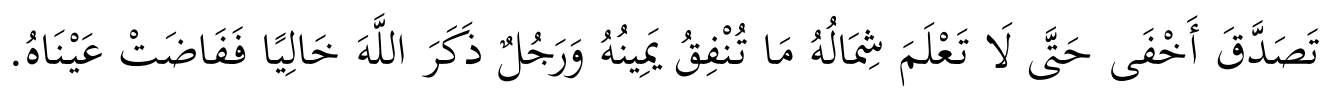

Artinya: "Hadis Muhammad ibn Basysyar ibn Dar, katanya hadis Yahya dari Abdullah katanya hadis dari Khubâib ibn Abdurrahman dari Hafs ibn 'Aśim dari Abu

${ }^{26}$ Ahmad Izan, dkk., Tafsir pendidikan Studi Ayat-ayat Berdimensi pendidikan, (Tangerang: Shuhuf Media Insani, 2012), hlm. 228. 


\section{Ahmad Syaifulloh}

Hurairah r.a., Rasulullah saw.bersabda: Tujuh orang yang akan dinaungi oleh Allah di naungan-Nya yang tidak ada naungan kecuali naungan Allah; pemimpin yang adil, pemuda yang tumbuh dalam keadaan taat kepada Allah; seorang yang hatinya terikat dengan masjid, dua orang yang saling mencintai karena Allah (mereka bertemu dan berpisah karena Allah), seorang yang diajak oleh wanita terpandang dan cantik namun ia berkata : saya takut kepada Allah, seorang yang menyembunyikan sedekahnya sampai tangan kirinya tidak mengetahui apa yang diberikan oleh tangan kanannya dan orang yang mengingat Allah dalam kesendirian hingga air matanya mengalir." (al-Bukhari, t.t, I: 234).

Dalam hadits tersebut dapat dipahami bahwa Rasulullah memberikan nasehat dengan menggunakan kalimat berita, tetapi di dalamnya mengandung nasehat yang menyeru agar umat Islam memiliki sifat-sifat tersebut sehingga menjadi manusia yang beruntung di dunia dan di akhirat. Bila dihubungkan dengan konteks pendidikan hadits yang mengandung pesan nasehat tersebut dapat menjadikan inspirasi dalam kegiatan pembelajaran, sehingga peserta didik mampu memahami dan melaksanakan nasehat yang terkandung dalam proses pembelajaran tersebut.

\section{Metode diskusi (mujadalah)}

Metode ini terdapat dalam QS. Nahl ayat 125, hal ini diketahui dari kata (bantahlah mereka dengan bantahan yang paling baik) atau dengan kata lain berdiskusilah dengan mereka melalui cara yang terbaik. Hal ini dapat menjadi inspirasi untuk melalukan pendidikan melalui metode diskusi.

Menurut Quraish Shihab, kata jâdilhum terambil dari kata jidâl yang bermakna diskusi atau bukti-bukti yang mematahkan alasan atau dalih mitra diskusi dan menjadikannya tidak dapat bertahan, baik yang dipaparkan itu diterima oleh semua orang maupun hanya mitra bicara. Selanjutnya, jadil juga adalah perdebatan dengan cara yang terbaik yaitu dengan logika dan retorika yang halus, lepas dari kekerasan 
dan umpatan. Sedangkan perintah berjadil disifati dengan kata ahsan/ yang terbaik, bukan sekedar yang baik. Dalam perspektif Quraish Shihab, jadil terdiri dari tiga macam, yang buruk adalah yang disampaikan dengan kasar, yang mengundang kemarahan lawan, serta yang menggunakan dalil-dalil yang tidak benar, yang baik adalah yang disampaikan dengan sopan, serta menggunakan dalil-dalil atau dalih walau hanya yang diakui oleh lawan, tetapi yang terbaik adalah yang disampaikan dengan baik, dan dengan argumen yang benar lagi membungkam lawan. ${ }^{27}$

Dalam tafsirnya, Jalaluddin Abdurrahman bin Abi Bakar as-Suyuti menjelaskan kalimat tersebut maksudnya : “debatlah mereka dengan) debat (yang terbaik) seperti menyeru manusia kepada Allah dengan ayat-ayat-Nya dan menyeru manusia kepada hujah". 28

Jadi dalam ayat tersebut dapat dipahami bahwa metode mujadalah atau diskusi dapat menjadi sebuah metode pendidikan yang tepat untuk mendapatkan kebenaran melalui hujjah-hujjah atau argument-argument yang disampaikan dengan etika yang baik tidak merasa paling benar atau arogan, guru lebih mudah untuk mengarahkan peerta didik, begitu pula peserta didik dapat lebih active dalam kegiatan belajar mengajar.

Metode ini dapat dikembangkan berdasarkan tingkat pendidikan peserta didik. Dan hendaknya dalam proses pendidikan,jidal/mujadalah bi al-lati hiya

\footnotetext{
${ }^{27}$ M. Quraish Shihab, Tafsir Al-Misbba, hlm. 776.

${ }^{28}$ Jalaluddin Muhammad bin Ahmad Al-Mahalli dan Jalaluddin Abdurrahman bin Abi Bakar As-Suyuti, Tafsir AlJalâlain, (Surabaya: Maktabah Dâr Ihya' al-Kutub al-'Arabiyyah Indonesia, 1414H), h. 226.
} 


\section{Ahmad Syaifulloh}

ahsan secara esensiail diartikan sebagai metode diskusi yang dilaksanakan dengan baik sesuai dengan nilai Islami. Proses diskusi bertujuan menemukan kebenaran, memfokuskan diri pada pokok permasalahan. Peserta diskusi hendaknya menggunakan akal sehat dan jernih, menghargai pendapat orang lain, memahami tema pembahasan, antusias, mengungkapkan dengan baik, dengan santun, dapat mewujudkan suasana yang nyaman dan santai untuk mencapai kebenaran serta memuaskan semua pihak. Di samping itu guru juga dapat menjadi penengah atau penjelas apa yang telah dihasilkan oleh diskusi tersebut. Sehingga pembelajaran dapat lebih baik dan saling active baik peserta didik maupun guru.

Mengenai motede diskusi ini terdapat sebuah hadits riwayat Imam Bukhari yang relevan, yaitu :

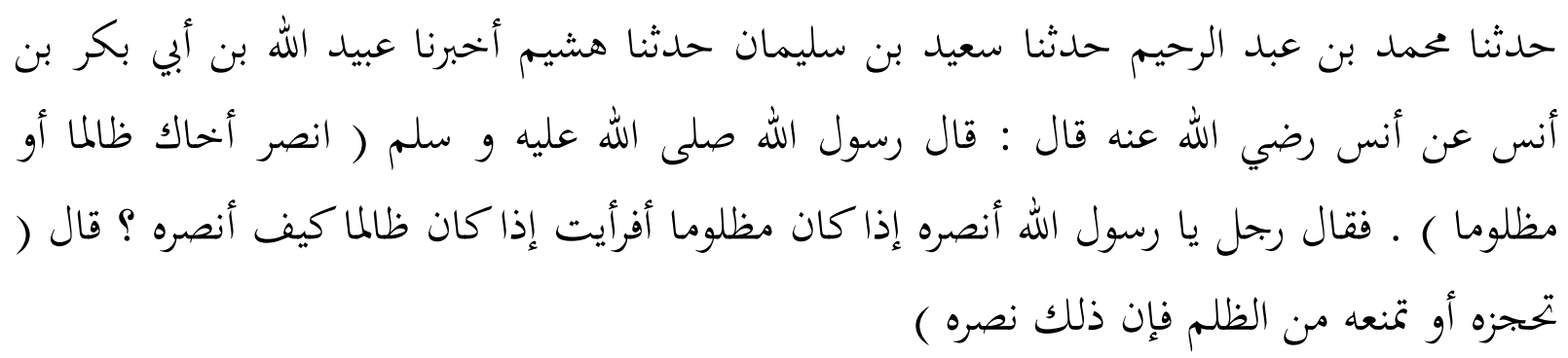

Artinya: "telah menceritakan kepadaku Muhammad bin Abdu ar-Rahim dari sa'id bin Sulaiman dari hasyim dari Abdullah bin Abi Bakr bin Anas dari Annas ra, berkata: Rasulullah SAW, bersabda: "tolonglah saudaramu yang dzalim dan yang didzalimi, kemudian seorang laki-laki bertanya :Ya Rasulallah aku menolongnya ketika terdzalimi, bagaimana jika menolong orang yang dzalim? Rasulullah menjawab: tahanlah (hentikanlah) dia dari kedzalimannya, karena sesungguhnya itu merupakan pertolongan padanya". (HR. Bukhari). ${ }^{29}$

Dari hadits tersebut dapat diketahui bahwa Rasulullah telah berdiskusi kepada sahabat tentang member pertolongan kepada orang yang dzalim dan yang

${ }^{29}$ Muhammad bin Ismail al-Bukhari, Shohih Bukhari, (al-maktabah ats-Tsamilah, 1987), hadits no. 6552. 
terdzalimi. Sehingga para sahabat dapat mengetahui dengan jelas apa yang disampaikan oleh Rasulullah dan mendapatkan penjelasan lebih lanjut ketika mereka belum faham melalui majlis diskusi. Para sahabat pun bebas mengeluarkan pendapat dan pertanyaan mereka. Sehingga terjadi suasana yang kondusif dan active dalam majlis tersebut.

Berdasarkan al-Quran dan Hadits tersebut metode diskusi dapat memiliki dasar dalam pendidikan Islam, sehingga metode ini dapat dikembangkan sebagai sebuah metode yang tepat dalam proses pendidikan. Peserta didik akan lebih active dalam kegiatan pembelajaran, sehingga mereka bisa lebih paham terdapat permasalahan yang menjadi tema diskusi dan mereka dapat terlatih mentalnya dalam menyampaikan pendapatnya serta dapat terlatih dalam menyelesaikan permasalahan yang terjadi.

\section{Metode Demonstrasi}

Metode demonstrasi ini terdapat dalam Surat al-Kahfi ayat 77. Dalam ayat ini menceritakan tentang bergurunya Nabi Musa kepada Nabi Khidir dan ayat ini berhubungan dengan ayat-ayat sebelumnya maupun sesudahnya, yaitu surat alKahfi ayat 60-82. Ayat-ayat tersebut mencerikan tentang proses pencarian Nabi Khidir oleh Nabi Musa, menjadi murid, hingga mereka berpisah lagi. Dalam ayatayat tersebut terdapat proses pembelajaran yang dilakukan oleh Nabi Khidir dalam memberikan ilmu kepada Nabi Musa melalui praktek langsung atau metode 


\section{Ahmad Syaifulloh}

demonstrasi, dengan melubangi kapal nelyan miskin untuk menyelmtkan mereka dari penguasa dzalim yang hendak mengambil tip kapal yang bagus, membunuh anak kecil karena kelak jika dewasa anak tersebut aka menjadi anak yang durhaka dan agar orang tua mereka dikaruniai anak yang shaleh sebagai gantinya, dan menegakkan diding rumah anak yatim yang di bawahnya tersimpan harta kekayaan orang tua mereka dengan maksud agar harta tersebut tidak diketahui para penduduk desa yang dzalim yang ingin menambilnya dan agar masih tersimpan untuk digunakan kelak ketika anak itu dewasa.kemudian Nabi Khidir memberikan penjelasan tentang hal-hal yang dipraktekkan tersebut yang belum diketahui oleh Nabi Musa tentang hakikat atau sebab-sebab Nabi Khidir melakukannya.

Dalam menafsirkan ayat ini Imam Ibnu Katsir menerangkan bahwa : Maka keduanya berjalan; hingga tatkala keduanya sampai kepada penduduk suatu negeri, mereka minta dijamu kepada penduduk negeri itu, tetapi penduduk negeri itu tidak mau menjamu mereka, Kemudian keduanya mendapatkan dalam negeri itu dinding rumah yang hampir roboh (condong), Maka Nabi Khidhir menegakkan dinding itu dengan mengusapkan tangannya. Kemudian Nabi Musa berkata : kaum yang telah kita datangi kemudian mereka tidak menjamu kita dan tidak menerima kita sebagai tamu, Jikalau kamu mau, niscaya kamu mengambil upah untuk itu. ${ }^{30}$ Imam alBaghawi juga memberikan keterangan yang sama tetang hal tersebut. Kemudian albaghawi meriwayatkan sebuah hadits riwayat Imam Bukhari tentang hal tersebut :

\footnotetext{
${ }^{30}$ Ibnu Katsir, Tafsir al-Quran al-adzim, juz. 5, hlm. 176.
} 


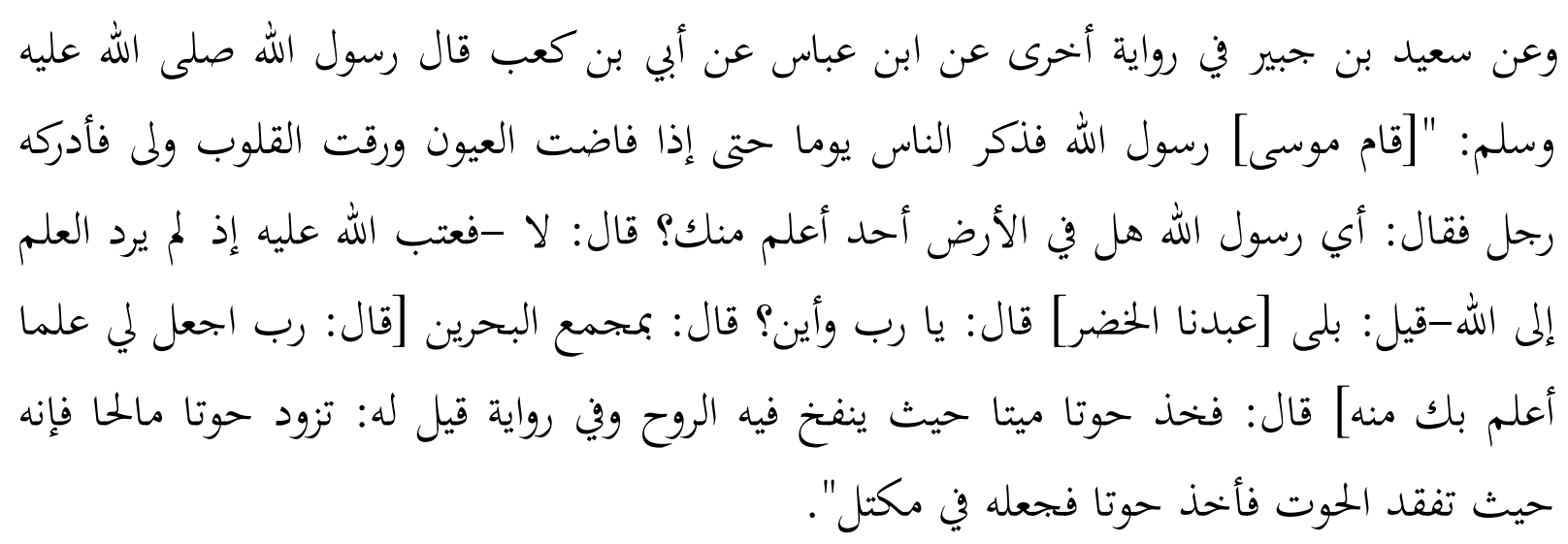

"Hadits dari Sa'id bin Jabir, dalam riwayat lain dari Ibnu Abbas dari Ubay in Ka'b, Rasulullah saw bersabda: "Rasulullah Musa berdiri pada hari orang-orang menyebutkan hingga ketika mata membanjiri dan hati dicuri pergi, membuat seorang pria bertanya kepada Musa : wahai utusan Allah, Apakah di Bumi ini terdapat seseorang yang lebih 'alim (pandai) dari pada engkau? Musa menjawab : Tidak, kemudian Allah menegurnya karena tidak menginginkan ilmu kepada Allah, dikatakan kepada Musa : ada (utusan Allah yang lebih pandai yaitu Nabi Khidir). Musa bertanya : ya Rabbi, dimana dia? Allah menjawab : di pertemuan kedua lautan (Musa berkata: Ya Rabbi, jadikanlah untukku ilmu yang aku bisa mengetahui dengan engkau darinya). Allah menjawab : ambillah ikan yang mati sekiranya dapat diberikan Ruh, dalam sebuah riwayat dikatakan : berbekallah ikan yang digoreng, maka sesungguhnya dia berada saat sekiranya kamu kehilangan ikan tersebut, kemudian Nabi Musa mengambil ikan dan memasukkannya ke tempat ikan."31

Dari keterangan ayat di atas, dapat diketahui bahwa Nabi Khidir sebagai seorang guru memberikan ilmunya kepada nabi Musa menggunakan metode praktik langsung, yang jika dihubungkan dengan pendidikan hal itu termasuk metode demonstrasi, yaitu metode mengajar dengan menggunakan alat peragaan (meragakan), untuk memperjelas suatu pengertian, atau untuk memperlihatkan bagaimana untuk melakukan dan jalannya suatu proses pembuatan tertentu kepada siswa.

${ }^{31}$ Abu Muhammad al-Husain bin Mas’ud al-Baghawi, Mu'alim at-Tanzil, (al-Maktabah ats-Tsamilah, 1997), juz. 5, hlm. 184. 


\section{Ahmad Syaifulloh}

Terdapat sebuah hadits yang selaras dengan metode demonstrsi tersebut, yaitu :

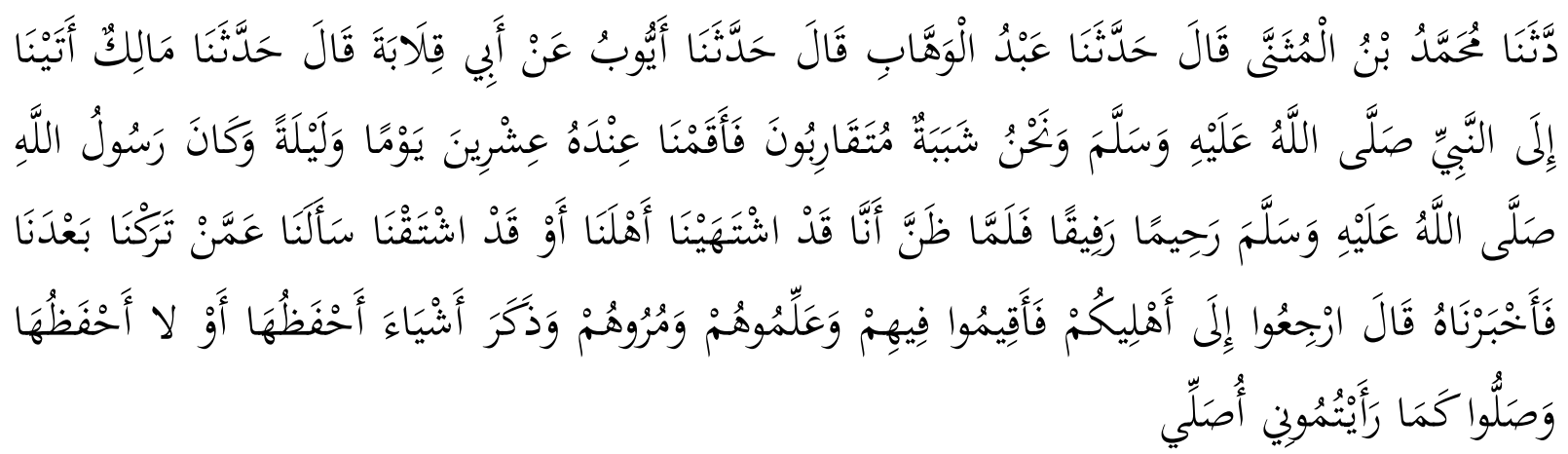

Artinya: "Hadis dari Muhammad ibn Muşanna, katanya hadis dari Abdul Wahhâb katanya Ayyũb dari Abi Qilâbah katanya hadis dari Mâlik. Kami mendatangi Rasulullah saw. dan kami pemuda yang sebaya. Kami tinggal bersama beliau selama (dua puluh malam) 20 malam. Rasulullah saw adalah seorang yang penyayang dan memiliki sifat lembut. Ketika beliau menduga kami ingin pulang dan rindu pada keluarga, beliau menanyakan tentang orangorang yang kami tinggalkan dan kami memberitahukannya. Beliau bersabda; kembalilah bersama keluargamu dan tinggallah bersama mereka, ajarilah mereka dan suruhlah mereka. Beliau menyebutkan hal-hal yang saya hapal dan yang saya tidak hapal. Dan salatlah sebagaimana kalian melihat aku salat." (al-Bukhari, I: 226)

Tentang kualitas, hadis di atas termasuk hadits syarîf marfu' dengan kualitas perawi yang sebagian tergolong şiqah dan şiqah kaşir, şiqah şubut. Hadits ini sangat jelas menunjukkan tata cara salat Rasulullah saw. kepada sahabat, sehingga para sahabat dipesankan oleh Rasulullah saw. agar shalat seperti yang dicontohkan olehnya. Kemudian mereka bisa mengajari keluarga mereka dengan mempraktekkannya.

Metode demonstrasi dimaksudkan sebagai suatu kegiatan memperlihatkan suatu gerakan atau proses kerja sesuatu yang bersifat praktek dan sulit untuk disampaikan hanya lewat teori saja, sehingga hal itu mudah dipahami. Pekerjaannya dapat saja dilakukan oleh guru atau pesert didik yang diminta mempraktekkan 
sesuatu pekerjaan. Metode demonstrasi dapat dipergunakan dalam organisasi pelajaran yang bertujuan memudahkan informasi dari model (model hidup, model simbolik, deskripsi verbal) kepada anak didik sebagai pengamat. Juga metode ini sangat cocok untuk pembelajaran tatacara shalat, bersuci, membaca al-Quran, olah raga, obervasi, dan lain-lain.

Melalui metode ini diharapkan peserta didik dapat paham betul tentang apa yang diajarka, karena kebayakan siswa tidak bisa mengerti dengan baik dan benar hanya lewat teori saja. Metode demonstrasi ini merupakan metode yang sangat efektif dalam membantu anak didik untuk menjawab kebutuhan belajarnya dengan usaha sendiri berdasarkan fakta dan data yang jelas dan benar yang diperolehnya dari demonstrasi.

Metode ini dapat menjadikan perhatian siswa lebih mudah dipusatkan pada proses belajar dan tidak tertuju pada hal-hal lain, dan dapat mengurangi kesalahan dalam mengambil kesimpulan, apabila dibandingkan dengan halnya membaca buku karena siswa mengamati langsung terhadap suatu proses yang jelas, serta apabila siswa turut aktif dalam sesuatu percobaan yang bersifat demonstrative maka anak didik akan memperoleh pengalaman-pengalaman praktis yang dapat membentuk perasaan dan kemampuan anak, serta dapat mengembangkan kecakapannya. Demikian juga metode demonstrasi akan menjadi metode yang kurang tepat apabila alat-alat yang dimonstrasikan tidak memadai atau tidak sesuai kebutuhan, tidak diikuti dengan sebuah aktivitas dimana siswa sendiri dapat ikut bereksperimen dan 


\section{Ahmad Syaifulloh}

tidak dapat menjadikan aktivitas itu sebagai pengalaman yang berharga. Maka halhal tersebut harus lebih diperhatikan agar metode ini dapat menjadi metode yang tepat dan menjadikan siswa lebih active dan paham terhadap pelajaran.

\section{E. PENUTUP}

Dari berbagai uraian di atas, dapat kita simpulkan bahwa terdapat beberapa metode pendidikan dalam al-Quran di antaranya : metode bercerita (QS. Huud ayat 120), metode tanya jawab (QS. al-Baqarah ayat 189), metode hikmah, nasehat, diskusi (QS. an-Nahl ayat 125), dan metode demonstrasi (QS. al-Kahfi ayat 77), dan hal itu dikuatkan dengan berbagai hadits yang sesuai dengan metode-metode tersebut.

Sebenarnya masih banyak metode-metode pendidikan yang terkandung dalam al-Quran yang belum terungkap dalam tulisan ini. Semoga tulisan ini ikut mewarnai dalam pemahaman al-Quran tentang pendidikan, sehingga dapat menjadi manfaat bagi pembacanya. 


\section{DAFTAR PUSTAKA}

Ath-Thobarii, Abu Ja'far Muhmaad ibn Jarir. 1996. Tafsir Ath-Thobari ; Jami'ul BAyan Ta'wilul Qur'an. Bairut-Libanon : Darul kutubul Ilmiuah.

al-Baghawi, Abu Muhammad al-Husain bin Mas'ud. 1997. Mu'alim at-Tanzil. alMaktabah ats-Tsamilah.

Izan, Ahmad. dkk. 2012. Tafsir pendidikan Studi Ayat-ayat Berdimensi pendidikan. Tangerang: Shuhuf Media Insani.

Munib, Ahmad dkk. 2004. Pengantar Ilmu Pendidikan. Semarang UPK MKK Unnes.

Al-Maraghy. 1974.Tafsir Al-Maraghy. Terj. Hery Noer Ali, dkk. Semarang : Toha Putra.

An-Naisaburi.1996. Tafsir Ghoroibil Qur'an wa roghoibil Furqon. Bairut-Libanon : Darul kutubul Ilmiuah.

al-Hanafi, Badru ad-Din al-'Aini. 'Umdatu al-Qori Sarh Shohih al-Bukhari. al-Maktabah ats-Tsamilah.

Hamka. 1992. Tafsir Al-Azhar. Jakarta : Pustaka Panjimas.

Al-Habsy, Husen. 1989. Kamus Arab Lengkap. Bangil : YAPPI.

Ibnu Katsir. 1980. Tafsir Ibnu Katsir. Beyrut : Daarul Fikri.

Al-Qurtubi. 1993. Al-Jami'ul Ahkam Al-Qur'an. Bairut-Libanon : Darulkutub alilmiyah.

ad-Dimisqi, Ismail bin Umar bin Katsir. 1999. Tafsir al-Quran al-Adzim, al-Maktabah ats-Tsamilah.

SM, Ismail. 2008. Strategi Agama Islam Berbasis PAIKEM. Semarang: Rasail Media Group.

Al-Mahalli, Jalaluddin Muhammad bin Ahmad dan As-Suyuti, Jalaluddin Abdurrahman bin Abi Bakar. 1414 H. Tafsir Al-Jalâlain. Surabaya: Maktabah Dâr Ihya' al-Kutub al-'Arabiyyah Indonesia.

Shihab, M. Quraish. 2009. Tafsir Al-Mishbah, volume 6, cet. II. Jakarta: Lentera Hati. Abu Fadl, Muhamad al-Alusy. tt. Ruhul Ma'ani. al-Maktabah ats-Tsamilah. 


\section{Ahmad Syaifulloh}

al-Bukhari, Muhammad bin Ismail. 1987. Shohih Bukhari. al-maktabah ats-Tsamilah. ar-Razi, Muhammad bin Umar. Mafatihul Ghoib. al-Maktabah ats-Tsamilah.

Sudjana, Nana. 1995. Dasar-Dasar Proses Belajar Mengajar. Bandung: Sinar Baru Algesindo. Al-Zuhaeli, Wahbah. 1991. Tafsir Munir. Damasqus : Darul Fikri.

Darajat, Zakiah. 1985. Metodik Khusus Pengajaran Agama Islam. Jakarta: Direktorat Jendral Pembinaan Kelembagaan Agama Islam. 
Pendekatan Holistik (Whole Language) Dalam Meningkatkan Pembelajaran Bahasa Arab 